\title{
Prolonged Pulmonary Exposure to Diesel Exhaust Particles Exacerbates Renal Oxidative Stress, Inflammation and DNA Damage in Mice with Adenine-Induced Chronic Renal Failure
}

\author{
Abderrahim Nemmar ${ }^{a}$ Turan Karaca $^{\mathrm{b}}$ Sumaya Beegam ${ }^{\mathrm{a}}$ Priya Yuvaraju \\ Javed Yasin ${ }^{c}$ Naserddine Kamel Hamadi ${ }^{d}$ Badreldin H. Alie
}

\begin{abstract}
aDepartment of Physiology, College of Medicine and Health Sciences, United Arab Emirates University, Al Ain, UAE; ' ${ }^{b}$ Department of Histology and Embryology, Faculty of Medicine, Trakya University, Edirne, Turkey; 'Department of Internal Medicine, dDepartment of Pharmacology, College of Medicine and Health Sciences, United Arab Emirates University, Al Ain, UAE; eDepartment of Pharmacology and Clinical Pharmacy, College of Medicine \& Health Sciences, Sultan Qaboos University, Al-Khod, Sultanate of Oman
\end{abstract}

\section{Key Words}

Air pollution $•$ Diesel exhaust particles $\bullet$ Adenine $\bullet$ Chronic kidney failure $\bullet$ Mice $•$ DNA damage - Oxidative stress

\begin{abstract}
Background/Aims: Epidemiological evidence indicates that patients with chronic kidney diseases have increased susceptibility to adverse outcomes related to long-term exposure to particulate air pollution. However, mechanisms underlying these effects are not fully understood. Methods: Presently, we assessed the effect of prolonged exposure to diesel exhaust particles (DEP) on chronic renal failure induced by adenine $(0.25 \% \mathrm{w} / \mathrm{w}$ in feed for 4 weeks), which is known to involve inflammation and oxidative stress. DEP $(0.5 \mathrm{~m} / \mathrm{kg})$ was intratracheally (i.t.) instilled every $4^{\text {th }}$ day for 4 weeks (7 i.t. instillation). Four days following the last exposure to either DEP or saline (control), various renal endpoints were measured. Results: While body weight was decreased, kidney weight increased in DEP+adenine versus saline+adenine or DEP. Water intake, urine volume, relative kidney weight were significantly increased in adenine+DEP versus DEP and adenine+saline versus saline. Plasma creatinine and urea increased and creatinine clearance decreased in adenine+DEP versus DEP and adenine+saline versus saline. Tumor necrosis factor $\alpha$, lipid peroxidation and reactive oxygen species were significantly increased in adenine+DEP compared with either DEP or adenine+saline. The antioxidant calase was significantly decreased in adenine+DEP compared with either adenine+saline or DEP. Notably, renal DNA damage was significantly potentiated in
\end{abstract}




\section{Cellular Physiology Cell Physiol Biochem 2016;38:1703-1713 and Biochemistry Published online: May 03, $2016 \quad$\begin{tabular}{l|l} 
DOI: 10.1159/000443109 & $\begin{array}{l}\text { (c) 2016 The Author(s). Published by S. Karger AG, Basel } \\
\text { www.karger.com/cpb }\end{array}$
\end{tabular} \\ Nemmar et al.: Prolonged Exposure to Diesel Particles and Chronic Renal Failure}

adenine+DEP compared with either adenine+saline or DEP. Similarly, systolic blood pressure was increased in adenine+DEP versus adenine+saline or DEP, and in DEP versus saline. Histological evaluation revealed more collagen deposition, higher number of necrotic cell counts and dilated tubules, cast formation and collapsing glomeruli in adenine+DEP versus adenine+saline or DEP. Conclusion: Prolonged pulmonary exposure to diesel exhaust particles worsen renal oxidative stress, inflammation and DNA damage in mice with adenine-induced chronic renal failure. Our data provide biological plausibility that air pollution aggravates chronic renal failure.

(C) 2016 The Author(s)

Published by S. Karger AG, Basel

\section{Introduction}

It is well established by epidemiological, clinical and experimental studies that air pollution, in general, and particulate air pollution, in particular, have a detrimental effect on the health and may affect various systems [1]. Diesel exhaust particles (DEP) is one of the major sources of particulate air pollution with diameter $\leq 2.5\left(\mathrm{PM}_{2.5}\right)$ and ultrafine particles (UFP) with diameter $\leq 0.1 \mu \mathrm{m}$ in in urban area [1]. Several studies have established that DEP adversely affect the respiratory system [2, 3]. Moreover, it has been demonstrated that, as a result of their small size, inhaled UFP (nano-sized) can affect distant organs either by direct passage across the alveolar capillary barrier and/or by the release of inflammatory mediators and markers of oxidative stress which may affect several distant organs including the heart, brain or kidney [1].

The prevalence of chronic renal failure (CRF) has significantly augmented attaining epidemic proportions worldwide attaining around $10 \%$ of some populations [4]. Lung and kidney function are closely interconnected under physiological and pathophysiological conditions. It has been well-established that pulmonary injury can exacerbate kidney failure [5]. Moreover, it is well-established that elderly people and those with pre-existing chronic diseases such as diabetes or hypertension are more vulnerable to the adverse effect of air pollution [6]. Since patients with CRF exhibit state of increased inflammation and oxidative stress, it is, therefore, conceivable that these patients are more susceptible to particulate air pollution $[7,8]$. In fact, it has been recently demonstrated that living near a major roadway contributes to reduced renal function [9].

We have recently demonstrated that single and repeated exposure to DEP aggravated cisplatin-induced acute renal failure in vivo in rats [10-12] and in vitro using human embryonic kidney (HEK-293) cells, and that curcumin pretreatment significantly suppressed the observed DEP and cisplatin-induced cellular insults [13]. However, as far as we are aware, no study has investigated the possible exacerbating effect of prolonged exposure to DEP on animal model of CRF.

Consequently, the aim of this study was to investigate whether and to what extent does prolonged pulmonary exposure to DEP exacerbates renal inflammation, oxidative stress, DNA damage and histopathology in adenine-induced chronic renal failure in mice.

\section{Materials and Methods}

\section{Animals}

Male TO mice (25-30 g, HsdOla:TO, Harlan, UK) were housed in light (12-h light:12-h dark cycle), relative humidity of $50-60 \%$ and temperature-controlled $\left(22 \pm 1{ }^{\circ} \mathrm{C}\right)$ rooms. They had free access to commercial laboratory chow and were provided tap water ad libitum. They were randomly divided into four groups and housed in metabolic cages, to facilitate urine collection. The mice were weighed at the beginning of the experiment and just before sacrifice. mice were cared for under a protocol approved by the Animal Research Ethics Committee of our college, and according to the NIH Guide for the Care and Use of Laboratory Animals, NIH publication no. 85-23, 1985. 


\section{Cellular Physiology Cell Physiol Biochem 2016;38:1703-1713 \begin{tabular}{l|l} 
and Biochemistry Published online: May 03, 2016 & $\begin{array}{l}\text { DOI: } 2016 \text { The Author(s). Published by S. Karger AG, Basel } \\
\text { www.karger.com/cpb }\end{array}$
\end{tabular} \\ Nemmar et al.: Prolonged Exposure to Diesel Particles and Chronic Renal Failure}

Intratracheal (i.t.) instillation

We used diesel exhaust particles (DEP; SRM 2975) obtained from the National Institute of Standards and Technology (NIST, Gaithersburg, MD, USA) [14, 15]. We have recently analysed the size of DEP used in the present study by transmission electron microscopy and found a substantial amount of ultrafine (nano) sized particle aggregates and larger particle aggregates $(<1 \mu \mathrm{m}$ in largest diameter) [16]. DEP were suspended in sterile normal saline ( $\mathrm{NaCl} 0.9 \%)$ containing Tween 80 (0.01\%). To minimize aggregation, particle suspensions were always sonicated (Clifton Ultrasonic Bath, Clifton, NJ, USA) for 15 min and vortexed before their dilution and prior to i.t. administration. Control animals received normal saline containing Tween $80(0.01 \%)$.

\section{Treatments}

The animals were anesthetized with i.p. injection of ketamine $(75 \mathrm{mg} / \mathrm{kg})$ and xylazine $(10 \mathrm{mg} / \mathrm{kg})$, and placed supine with extended neck on an angled board. A Becton Dickinson 18 Gauge cannula was inserted via the mouth into the trachea. DEP suspension $(0.5 \mathrm{mg} / \mathrm{kg}$ in $150 \mu \mathrm{l})$ or saline were intratracheally (i.t.) instilled $(150 \mu \mathrm{l})$ via a sterile syringe and followed by an air bolus of $150 \mu \mathrm{l}$. Either DEP or saline was i.t. instilled every every $4^{\text {th }}$ day for 4 weeks ( 7 i.t. instillation). To induce CRF, mice received powdered diet containing adenine $(0.25 \% \mathrm{w} / \mathrm{w})$ in feed for four weeks in mice [17]. Control animals received normal food for the same period of time. On day 28, mice were placed in metabolic cage and urine was collected over a 24-h period and the volume measured. On day 29, systolic blood pressure (SBP) and various renal endpoints were measured.

\section{SBP measurement}

On day 29, the (SBP) was measured using a computerized noninvasive tail-cuff manometry system (ADInstrument, Colorado Springs, CO, USA). To avoid procedure-induced anxiety, mice were trained for 3 consecutive days before the experimental procedure.

\section{Blood collection and biochemical analysis}

Following SBP measurement, the same animals were sacrificed with an overdose of anesthesia and kidneys were excised, washed with ice-cold saline, blotted with filter paper and weighed. The cortex of the right kidney was excised away from the medulla, and rapidly homogenized in ice-cold normal saline to produce $10(\mathrm{w} / \mathrm{v})$ tissue homogenate.

The concentrations of urea and creatinine in serum were spectrophotometrically measured using commercial kits (Roche Diagnostics, Indianapolis, IN, USA). The activity of catalse (Cayman Chemicals, MI, USA), and the concentrations of tumour necrosis factor $\alpha$ (TNF $\alpha$ ) (R \& D systems, MN, USA) were measured using commercially-available kits in renal cortex homogenates. The determination of reactive oxygen species (ROS) and lipid peroxidation levels in kidney homogenates were performed as previously described [18-23]. For the assessment of DNA damage, kidneys were removed immediately after the sacrifice, and the comet assay was performed as previously described [24]. The measurement of length of the DNA migration (i.e. diameter of the nucleus plus migrated DNA) was calculated using the image analysis Axiovision 3.1 software (Carl Zeiss, Canada) [25].

\section{Histopathology}

From each animal in the experiment, a small piece of the left kidney was fixed in 10\% neutral-buffered formalin, dehydrated in increasing concentrations of ethanol, cleared with xylene and embedded in paraffin. Five-micrometer sections were prepared from kidney paraffin blocks and stained with haematoxylin and eosin (H \&E), Masson's trichrome and Sirius red. Tubular damage was scored as follows: Each section was examined in 15 fields, and the average percentage of the impaired renal tubules was then calculated. The results of renal tubular damage were transformed into an index of renal tubular necrosis, where no damage was assigned a 0 index; $<25 \%$ damage was assigned 1; 25-50\% damage was assigned 2; 50-75\% damage was assigned 3 and $>75 \%$ damage was assigned a 4 index [26]. Renal fibrosis was quantified on Masson's trichrome and Sirius red-stained kidney paraffin sections. Fifteen microscopic areas per animal of randomly selected cortical areas were taken at 400X magnifications using a light microscope (Olympus CX31, Japan). Renal fibrosis: 0: normal kidney; grade 1: minimal fibrous thickening of perivascular or around tubular canals; grade 2: Medium thickening of perivascular or around tubular canals; grade 3: intensive fibrosis 


\section{Cellular Physiology Cell Physiol Biochem 2016;38:1703-1713 \begin{tabular}{l|l} 
and Biochemistry 10.1159/000443109 & $\begin{array}{l}\text { (c) 2016 The Author(s). Published by S. Karger AG, Basel } \\
\text { www.karger.com/cpb }\end{array}$
\end{tabular} \\ Nemmar et al.: Prolonged Exposure to Diesel Particles and Chronic Renal Failure}

thickening perivascular or around tubular canals; grade 4: very intensive fibrosis thickening perivascular or around tubular canals.

\section{Statistics}

All data were analyzed with GraphPad Prism Version 4.01 for Windows software (Graphpad Software Inc., San Diego, USA). Data were analyzed for normal distribution using using the D'Agostino and Pearson omnibus normality test. Data are expressed as means \pm SEM. Comparisons between groups were performed by one way analysis of variance (ANOVA), followed by Newman Keuls test for comparing treated with control data. $\mathrm{P}$ values $<0.05$ are considered significant.

\section{Results}

Body weight, relative kidney weight, water intake and urine volume

Figure $1 \mathrm{~A}$ shows that the body weight of mice treated with saline increased about $1 \%$ their body weight, whereas the body weight of those given DEP significantly decreased by about $10 \%$ relative to their initial body weight $(\mathrm{P}<0.01)$. Remarkably, the decrease of weight was significantly aggravated in adenine + DEP versus adenine+saline $(P<0.05)$ or DEP $(\mathrm{P}<0.05)$ groups. Figure $1 \mathrm{~B}$ shows that the relative kidney weights were significantly increased in mice given adenine+DEP compared with adenine+saline $(\mathrm{P}<0.05)$ or DEP $(\mathrm{P}<0.05)$ groups. The water intake and urine volume were significantly augmented in the adenine+saline group compared with the saline group $(\mathrm{P}<0.001)$, and in adenine+DEP group compared with the DEP group $(\mathrm{P}<0.01)$ (Fig. 1C and 1D).

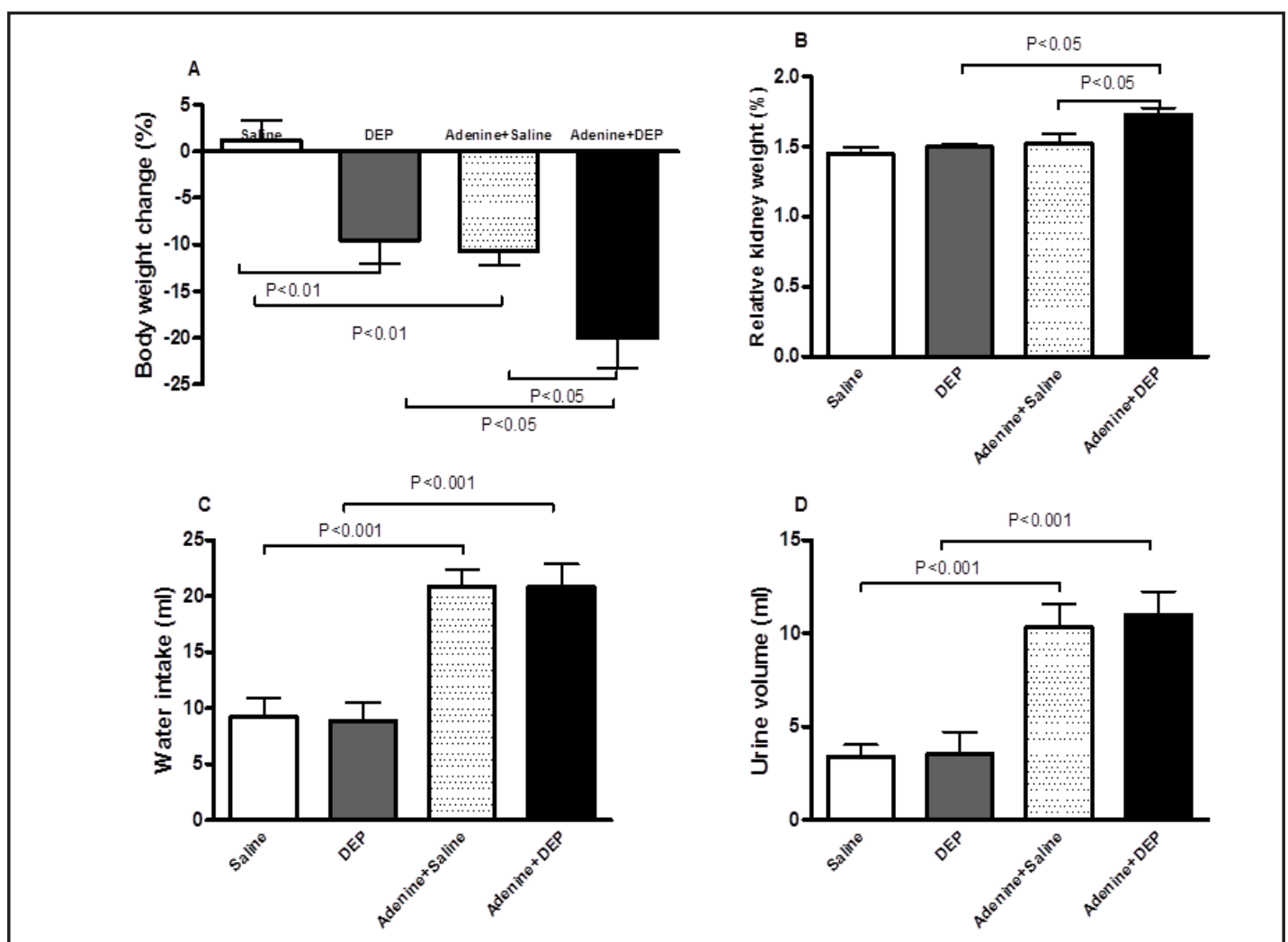

Fig. 1. Body weight change (A), relative kidney weight (B), water intake (C) and urine volume (D) in mice treated every $4^{\text {th }}$ day for 4 weeks (7 intratracheal instillation) with either saline (control) or diesel exhaust particles (DEP, $0.5 \mathrm{mg} / \mathrm{kg}$ ) with or without adenine administration in the feed $(0.25 \% \mathrm{w} / \mathrm{w}$, for four weeks) $(\mathrm{n}=6-8)$. Mean \pm SEM. Statistical analysis by ANOVA 1 followed by Newman-Keuls test. 
Fig. 2. Plasma concentrations of urea (A) and creatinine (B), and creatinine clearance (C) in mice treated every $4^{\text {th }}$ day for 4 weeks $(7$ intratracheal instillation) with either saline (control) or diesel exhaust particles (DEP, $0.5 \mathrm{mg} / \mathrm{kg}$ ) with or without adenine administration in the feed $(0.25 \% \mathrm{w} / \mathrm{w}$, for four weeks) $(n=6-8)$. Mean \pm SEM. Statistical analysis by ANOVA 1 followed by Newman-Keuls test.

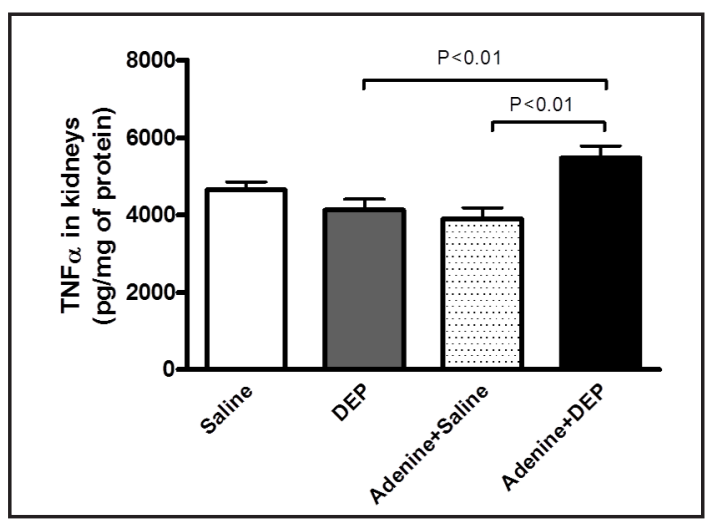

Fig. 3. Concentration of tumour necrosis factor $\alpha$ (TNF $\alpha$ ) in kidney homogenates of mice treated every $4^{\text {th }}$ day for 4 weeks (7 intratracheal instillation) with either saline (control) or diesel exhaust particles (DEP, $0.5 \mathrm{mg} / \mathrm{kg}$ ) with or without adenine administration in the feed $(0.25 \% \mathrm{w} / \mathrm{w}$, for four weeks) $(\mathrm{n}=7-8)$. Mean \pm SEM. Statistical analysis by ANOVA 1 followed by Newman-Keuls test.

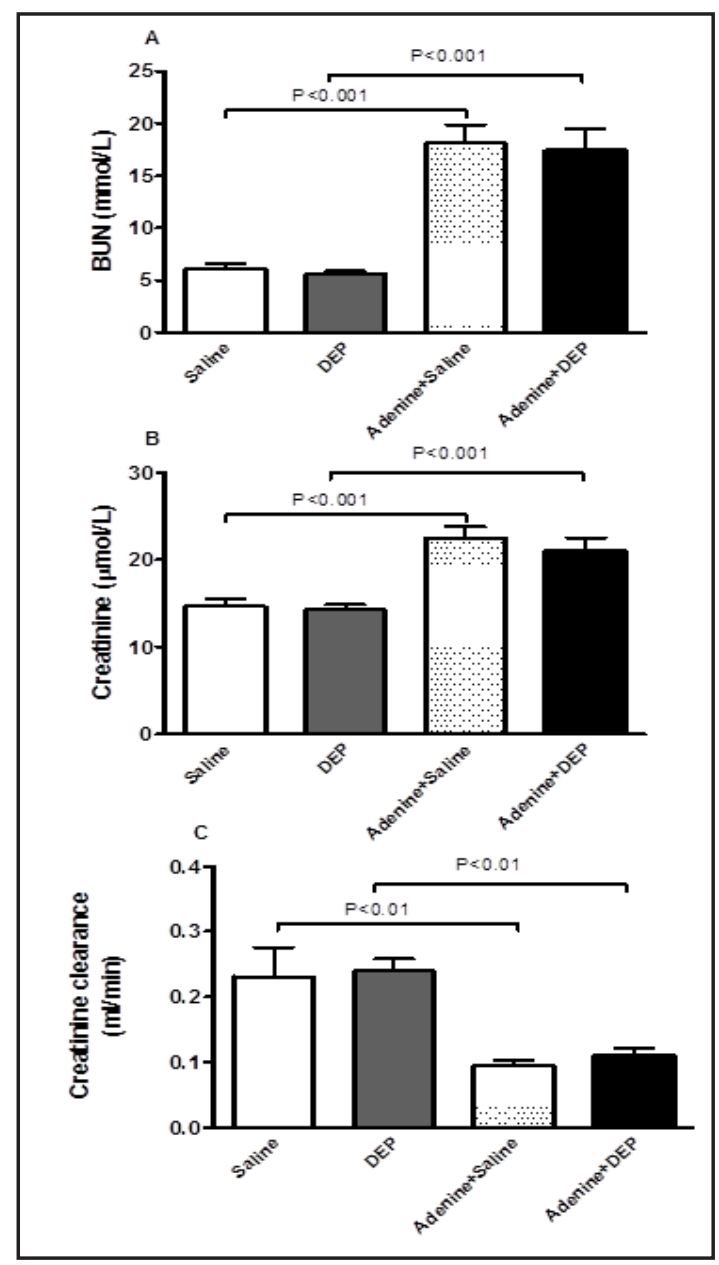

Plasma concentrations of creatinine and urea and creatinine clearance

There was no difference in urea and creatinine concentrations between saline and DEP groups. However, treatment with adenine+saline significantly increased the concentration of urea and creatinine compared with the saline-treated mice. Adenine+DEP treatment significantly augmented the concentrations of urea and creatinine compared with DEPtreated group (Fig. 2A and 2B).

Creatinine clearance was significantly decreased in adenine+saline compared with saline group $(\mathrm{P}<0.01)$ and in adenine+DEP compared with DEP-exposed mice $(\mathrm{P}<0.01)$.

\section{TNF $\alpha$ concentrations in kidney homogenates}

Figure 3 illustrates that treatment with adenine+DEP significantly increased the concentration of TNF $\alpha$ compared with adenine+saline $(\mathrm{P}<0.01)$ or DEP alone $(\mathrm{P}<0.01)$.

\section{LPO, ROS and catalase levels in kidney homogenates}

Figure 4A shows that DEP caused a slight but statistically insignificant increase in LPO compared with saline-treated group. Adenine+DEP treatment induced a significant increase of LPO in kidney homogenates compared with adenine+saline $(0.05)$ or DEP alone $(\mathrm{P}<0.001)$.

Compared with saline group, i.t. administration of DEP caused a significant increase of ROS in kidney homogenate $(\mathrm{P}<0.01)$. The levels of ROS in adenine+saline group were higher compared with saline group $(\mathrm{P}<0.01)$. Interestingly, adenine+DEP treatment caused a significant increase of ROS in kidney homogenates compared with adenine+saline $(\mathrm{P}<0.001)$ or DEP $(\mathrm{P}<0.001)$ (Fig. 4B).

\section{KARGER}


Fig. 4. Renal levels of lipid peroxidation (LPO, A), reactive oxygen species (ROS, B) and catalase (C) in mice treated every $4^{\text {th }}$ day for 4 weeks $(7$ intratracheal instillation) with either saline (control) or diesel exhaust particles (DEP, $0.5 \mathrm{mg} / \mathrm{kg}$ ) with or without adenine administration in the feed $(0.25 \%$ $\mathrm{w} / \mathrm{w}$, for four weeks) $(\mathrm{n}=7-8)$. Mean \pm SEM. Statistical analysis by ANOVA 1 followed by Newman-Keuls test.

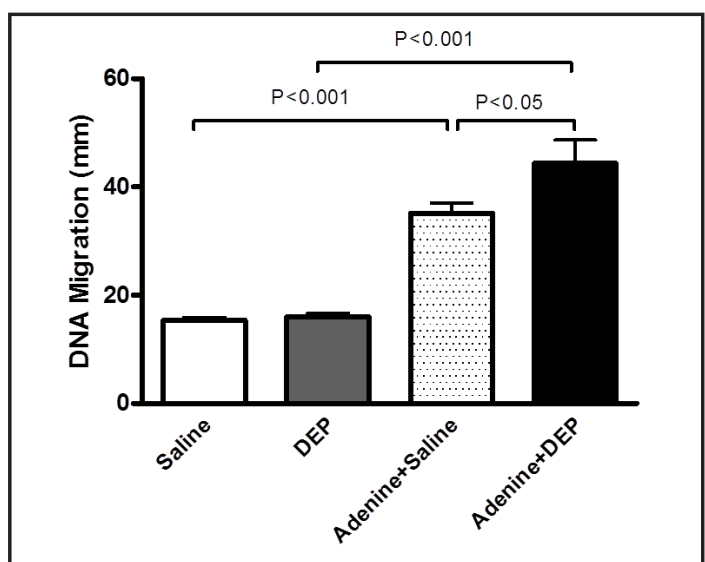

Fig. 5. DNA migration ( $\mathrm{mm}$ ) in the kidney tissues assessed by Comet assay in mice treated every $4^{\text {th }}$ day for 4 weeks ( 7 intratracheal instillation) with either saline (control) or diesel exhaust particles (DEP, 0.5 $\mathrm{mg} / \mathrm{kg}$ ) with or without adenine administration in the feed $(0.25 \% \mathrm{w} / \mathrm{w}$, for four weeks) $(\mathrm{n}=5)$. Mean \pm SEM. Statistical analysis by ANOVA 1 followed by Newman-Keuls test.
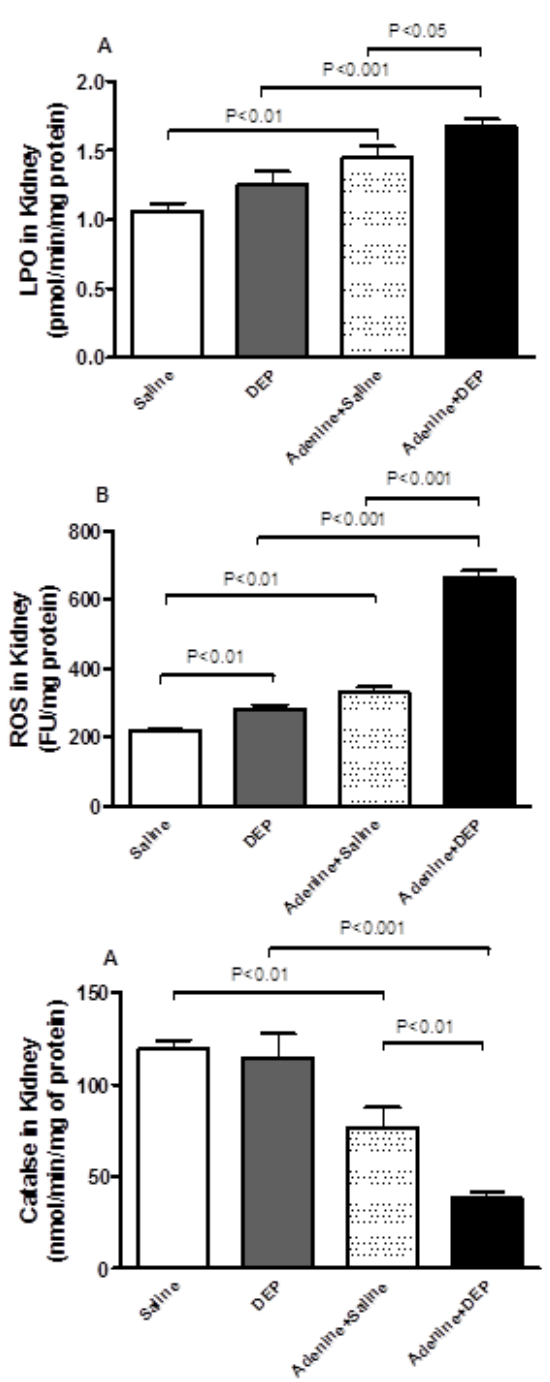

The activity of the antioxidant catalase significantly decreased in adenine+saline versus saline group $(\mathrm{P}<0.01)$. Of note, catalase activity was significantly reduced in adenine+DEP compared with adenine+saline $(\mathrm{P}<0.01)$ or DEP $(\mathrm{P}<0.001)$ groups (Fig. $4 \mathrm{C})$.

\section{Kidney DNA damage}

Figure 5 illustrates the effect of DEP or saline administration with or without adenine treatment on DNA migration assessed by COMET assay. Compared with saline group, DEP did not affect DNA migration. However, adenine+saline caused a significant DNA migration compared with saline group $(\mathrm{P}<0.001)$. More importantly, there was a significant DNA migration in adenine+DEP versus adenine+saline $(\mathrm{P}<0.05)$ or $\mathrm{DEP}(\mathrm{P}<0.001)$ groups.

\section{Histopathology}

Figure 6 illustrates representative micrographs of renal cortex from saline, DEP, adenine+saline and adenine+DEP groups. The kidney architecture was not affected by saline exposure. Histological evaluation (Fig. 6) and scoring (Fig. 7) revealed a higher number of necrotic cell counts, dilated tubules, cast formation and collapsing glomeruli in adenine+DEP compared with adenine+saline or DEP alone. A statistically significant increase in the scores of kidney injury (Fig. 7A) and fibrosis (Fig. 7B and 7C) were found in adenine+DEP versus 
Fig. 6. Representative light microscopy sections of renal tissues of mice stained with H\&E or Masson's trichrome or Sirius red. Mice were treated every $4^{\text {th }}$ day for 4 weeks (7 intratracheal instillation) with either saline (control) or diesel exhaust particles (DEP, $0.5 \mathrm{mg} / \mathrm{kg}$ ) with or without adenine administration in the feed $(0.25 \% \mathrm{w} / \mathrm{w}$, for four weeks). All magnifications: 400X. The saline group shows normal kidney architecture and histology. In adenine+DEP sections of renal tissues stained with H\&E, there was higher number of necrotic cell counts, dilated tubules, cast formation and collapsing glomeruli compared with adenine+saline or DEP sections. Masson's trichrome and Sirius red staining of renal sections shows more collagen deposition in adenine+DEP group compared with adenine+saline or DEP alone. See figure 7 for statistical analysis of scores of renal injury and fibrosis.

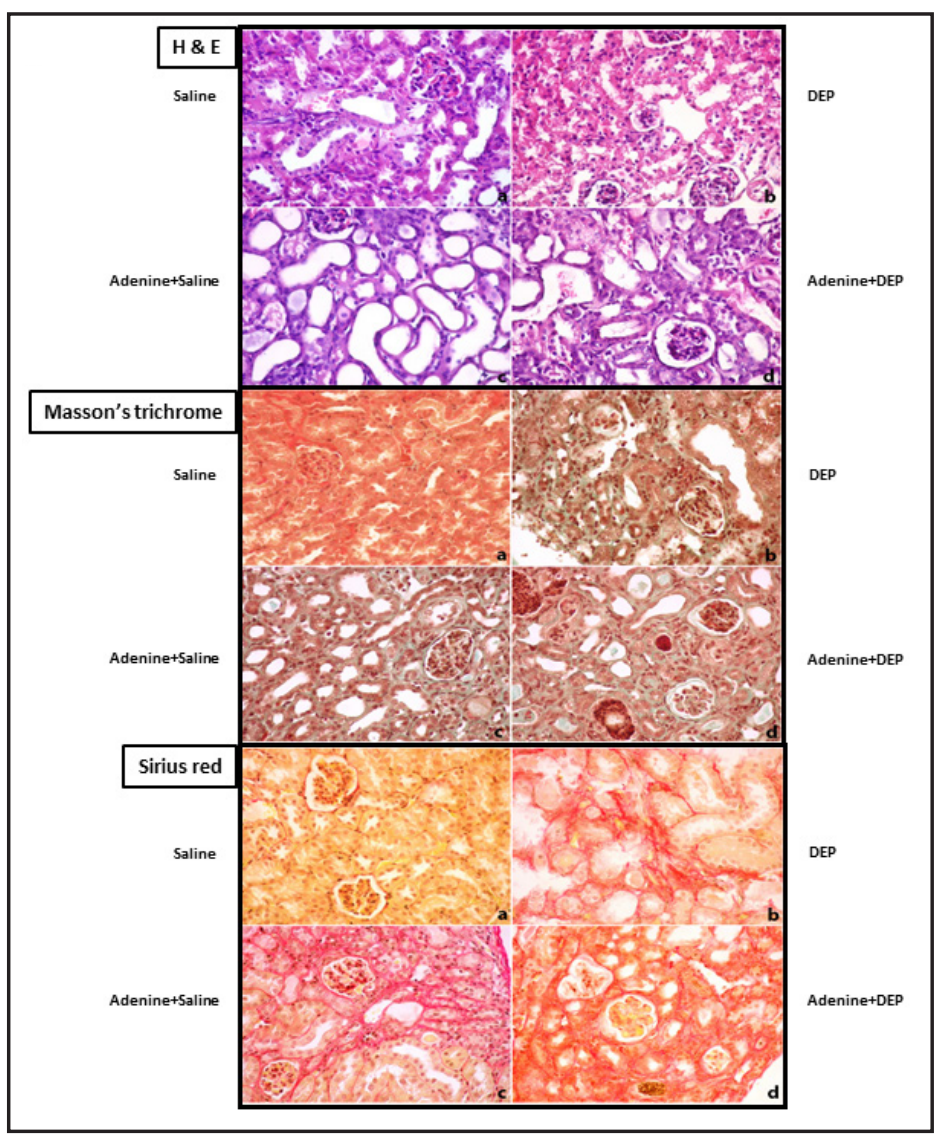

adenine+saline or DEP alone. A significant increase of injury and fibrosis was also found between DEP versus saline (Fig. 7).

\section{Systolic blood pressure}

DEP induced a significant increase of SBP compared with saline group. Adenine+saline significantly increased SBP compared with saline group. Remarkably, adenine+DEP significantly enhanced SBP compared with adenine+saline or DEP (Fig. 8).

\section{Discussion}

Our study demonstrated that prolonged pulmonary exposure to DEP aggravated renal inflammation, oxidative stress and DNA damage in a mouse model of CRF. Moreover, the histopathological analysis showed exacerbation of tubular necrosis, dilated tubules, cast formation and collapsing glomeruli along with increased of fibrosis in DEP+adenine group compared with adenine+saline or DEP.

It has been previously demonstrated that exposure to particulate air pollution affects various organs including the heart, lung and kidney, and that the at risk fraction of the population are those with pre-existing chronic diseases. Recently kidney transplant recipients and those undergoing peritoneal dialysis have been reported to be more susceptible to $\mathrm{PM}_{2.5}$ $[8,27]$. We have recently reported the effect of acute and subacute exposure to DEP in rat model of acute renal failure induced by cisplatin [11-13]. However, no study has investigated the potential deleterious effects of DEP on animal model of CRF, and the mechanisms underlying these effects.

Durable ingestion of adenine prevents the excretion of nitrogenous compounds by blocking of renal tubules, and producing metabolic disorders resembling CRF in humans $[17,28,29]$. In mammals, when adenine is present in excess, it becomes a major substrate 
Fig. 7. Renal injury scores in kidney tissues stained with H\&E (A) and renal fibrosis scores after Masson's (B) or Sirius red (C) staining in mice-treated every $4^{\text {th }}$ day for 4 weeks $(7$ intratracheal instillation) with either saline (control) or diesel exhaust particles (DEP, $0.5 \mathrm{mg} / \mathrm{kg}$ ) with or without adenine administration in the feed $(0.25 \% \mathrm{w} / \mathrm{w}$, for four weeks) $(n=6)$. Mean \pm SEM. Statistical analysis by ANOVA 1 followed by Newman-Keuls test.

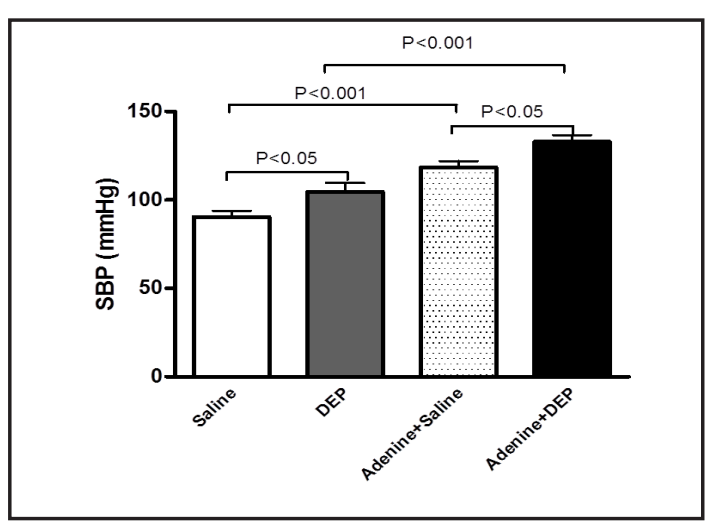

Fig. 8. Systolic blood pressure (SBP) in mice treated every $4^{\text {th }}$ day for 4 weeks $(7$ intratracheal instillation) with either saline (control) or diesel exhaust particles (DEP, $0.5 \mathrm{mg} / \mathrm{kg}$ ) with or without adenine administration in the feed $(0.25 \% \mathrm{w} / \mathrm{w}$, for four weeks) $(\mathrm{n}=8)$. Mean \pm SEM. Statistical analysis by ANOVA 1 followed by Newman-Keuls test.

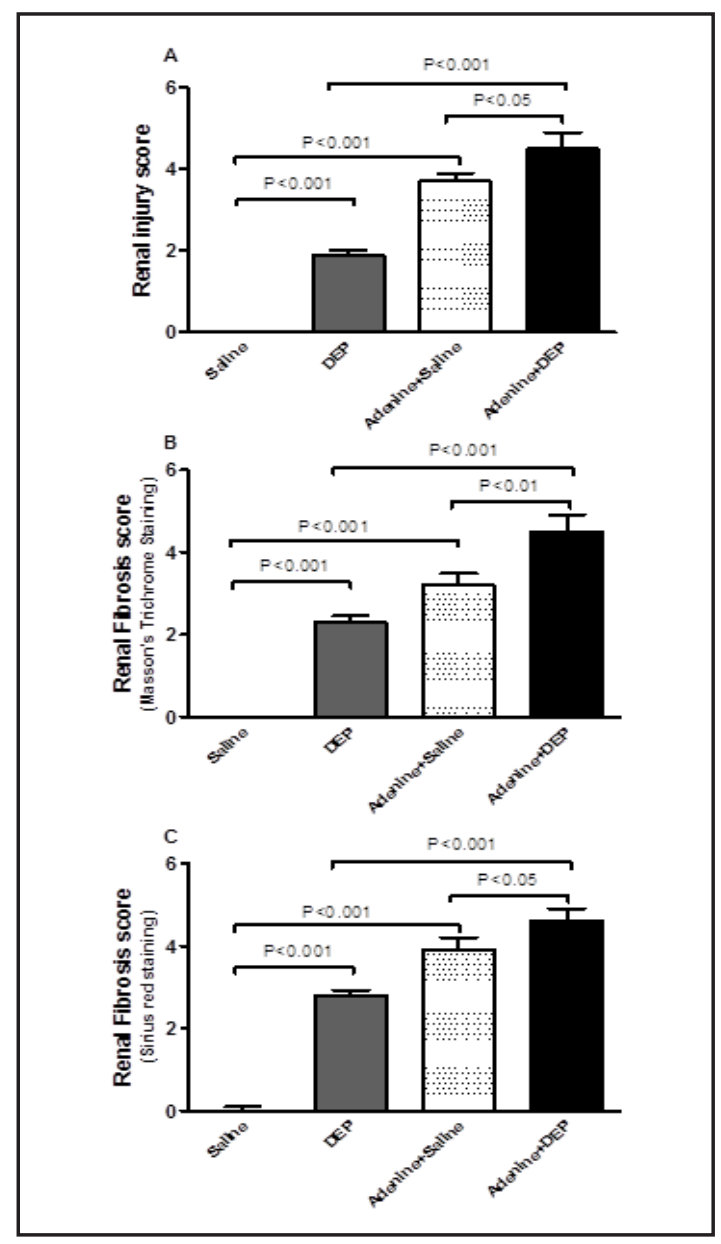

for xanthine dehydrogenase which is able to oxidize adenine to 2,8-dihydroxyadenine [17]. Both adenine and 2,8-dihydroxyadenine have low solubility, they deposit in renal tubules and induce oxidative stress and inflammation leading to renal damage [17]. Adenine has been widely used in rat to induce CRF [28-31]. In mice, we have recently demonstrated the occurrence of CRF with adenine at a dose of $0.2 \%, \mathrm{w} / \mathrm{w}$, for 4 weeks [17]. So, in the present study we used a relevant model of CRF in mice and assessed the possible aggravating effect of DEP on various renal parameters. The dose of DEP used here is analogous to numerous dosage treatments previously studied [32,33]. Mice were i.t. instilled with DEP because it represents a relevant way of exposure, because mice are obligate nose breathers which filter most inhaled particles [34].

Our data show that DEP exposure decreased body weight compared with control and that the concomitant treatment with adenine and DEP further aggravated the weight loss compared with DEP alone or the adenine +saline. The kidney weight was significantly increased in adenine+DEP versus adenine+saline or DEP but the increase was insignificant between adenine+DEP versus adenine+saline. Compared with saline or DEP, adenine+saline or adeine+DEP groups augmented their water intake and urine volume but no exacerbating effect was seen in mice treated with adenine+DEP versus those that received adenine+saline. Similar observations have been made in rats exposed to DEP and injected with cisplatin to induce acute renal failure [12]. Likewise, while both plasma concentrations of creatinine and urea were increased, creatinine clearance decreased in adenine+DEP and adenine+saline compared with DEP or saline, respectively. However, no difference has been observed between adenine+DEP compared with adenine+saline. These findings are in line with a recent study in rat model of ARF and exposed to DEP [12]. 


\section{Cellular Physiology Cell Physiol Biochem 2016;38:1703-1713 \\ \begin{tabular}{cc|c} 
DOI: 10.1159/000443109 & $\begin{array}{l}\text { O 2016 The Author(s). Published by S. Karger AG, Basel } \\
\text { wwww.karger.com/cpb }\end{array}$ \\
\cline { 2 - 3 }
\end{tabular} \\ Nemmar et al.: Prolonged Exposure to Diesel Particles and Chronic Renal Failure}

Patients with chronic kidney disease present states of augmented inflammation and oxidative stress. These latter states are major features of CRF and its resulting complications both clinically and experimentally $[29,35]$. These may conceivably make patients with chronic kidney disease at risk to air pollution [7]. It has been recently demonstrated that DEP potentiate oxidative stress in cisplatin-induced acute renal failure in rats and in HEK-293 cells in vitro, and that the pretreament with antioxidants including thymoquinone or curcumin mitigated DEP toxicity $[12,13,36]$. Here, we found no increase of TNF $\alpha$ in adenine+saline mice. This finding is not in agreement with a previous study which showed an increase in $\mathrm{TNF} \alpha$ expression in kidney of adenine-treated rats [37]. This discrepancy could be explained by duration of adenine treatment (16 weeks compared with 4 weeks applied here) and/or the difference in animal species (rats versus mice used here). Notably, in the present study, we show a significant increase of TNF $\alpha$ and markers of oxidative stress including LPO and ROS in adenine+DEP compared with adenine+saline or DEP alone. Moreover, we also show that the activity of antioxidant catalase was significantly more decreased in adenine+DEP versus adenine+saline or DEP alone, indicating a reduced antioxidant defence and hence augmented proneness to oxidative stress. This experimental finding provides, for the first time, a proof of concept that combination of CRF and particulate air pollution aggravate renal oxidative stress and inflammation, and may explain why patients with CRF are more susceptible to particulate air pollution.

ROS can cause impairment of mitochondrial activity, protein structure and DNA. The formation of DNA double strand breaks has been recently reported in the kidney of rat model of adenine-induced CRF and DOCA/salt model $[29,38]$. However, the possible aggravation of DNA damage by DEP in the kidney of animal model of CRF has not been reported before. In the present study, we assessed the degree of DNA damage by a well-validated method, i.e. COMET assay $[24,25]$, and confirmed its occurrence in adenine-treated mice. More importantly and similarly to the oxidative stress markers measured presently, we showed a significant increase in DNA damage in mice exposed to DEP+adenine compared with those administered with adenine+saline. This finding could be explained by the occurrence of oxidative stress which may lead to DNA damage. It remains to be established if antioxidant treatment can mitigate these effects. It has been recently shown that treatment with antioxidant Gum acacia mitigates genetic damage in adenine-induced chronic renal failure in rats $[29,39]$.

In line with the aggravation of the inflammation, oxidative stress and DNA damage parameters by the combination of adenine+DEP, the histological findings showed a higher number of necrotic cell counts, dilated tubules, cast formation and collapsing glomeruli in adenine+DEP compared with adenine+saline or DEP alone. Moreover, Masson's trichrome and Sirius red stained sections demonstrated higher collagen deposition in adenine+DEP mice compared with adenine+saline or DEP alone. It has been shown that inflammation plays a crucial role in renal cortical damage and interstitial fibrosis [40]. It is well established that the number of macrophages is increased in diseased kidney, where they play a key role in renal injury, inflammation, and fibrosis [40]. Additional studies are required to assess the role of macrophage-induced renal inflammation on its detrimental impact on kidney dysfunction following exposure to DEP.

It is well established that CRF has a major effect on the cardiovascular system both clinically and experimentally $[37,41]$. Rats with adenine-induced CRF have been reported to develop several cardiovascular disturbances including augmented SBP and impaired vascular reactivity [37]. Here, we confirm the increase of SBP in mice treated with adenine and show a significantly higher increase of SBP in mice treated adenine+DEP compared with either adenine+saline or DEP alone. An aggravation in SBP in rat model of acute renal failure induced by cisplatin injection has been recently reported [12].

We conclude that prolonged pulmonary exposure to DEP exacerbates renal oxidative stress, inflammation, DNA damage and histological changes in adenine-induced chronic renal failure in mice. Our data provide biological plausibility that patients with CRF are more vulnerable to particulate air pollution than healthy people. 


\section{Cellular Physiology Cell Physiol Biochem 2016;38:1703-1713

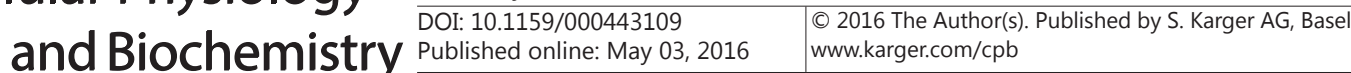 \\ Nemmar et al.: Prolonged Exposure to Diesel Particles and Chronic Renal Failure}

\section{Disclosure Statement}

No conflicts of interest, financial or otherwise, are declared by the author(s).

\section{Acknowledgements}

This work was supported by a UAEU-SQU joint grant provided to both Prof. A. Nemmar (UAEU) and Prof. B.H. Ali (SQU), and by a research grant of the College of Medicine and Health Sciences, United Arab Emirates University.

\section{References}

1 Nemmar A, Holme JA, Rosas I, Schwarze PE, Alfaro-Moreno E: Recent advances in particulate matter and nanoparticle toxicology: a review of the in vivo and in vitro studies. Biomed Res Int 2013;2013:279371.

2 Atkinson RW, Anderson HR, Sunyer J, Ayres J, Baccini M, Vonk JM, Boumghar A, Forastiere F, Forsberg B, Touloumi G, Schwartz J, Katsouyanni K: Acute effects of particulate air pollution on respiratory admissions: results from APHEA 2 project. Air Pollution and Health: a European Approach. Am J Respir Crit Care Med 2001;164:1860-1866.

3 Pope CA, III, Schwartz J, Ransom MR: Daily mortality and PM10 pollution in Utah Valley. Arch Environ Health 1992;47:211-217.

4 Stenvinkel P: Chronic kidney disease: a public health priority and harbinger of premature cardiovascular disease. J Intern Med 2010;268:456-467.

5 Pierson DJ: Respiratory considerations in the patient with renal failure. Respir Care 2006;51:413-422.

6 Brook RD, Rajagopalan S, Pope CA, Brook JR, Bhatnagar A, Diez-Roux AV, Holguin F, Hong YL, Luepker RV, Mittleman MA, Peters A, Siscovick D, Smith SC, Whitsel L, Kaufman JD: Particulate Matter Air Pollution and Cardiovascular Disease An Update to the Scientific Statement From the American Heart Association. Circulation 2010;121:2331-2378.

7 Laden F, Winkelmayer WC: Air pollution and coronary risk in kidney transplant recipients. Am J Kidney Dis 2011;58:506-507.

8 Huang WH, Yen TH, Chan MJ, Su YJ: Impact of environmental particulate matter and peritoneal dialysisrelated infection in patients undergoing peritoneal dialysis. Medicine (Baltimore) 2014;93:e149.

9 Lue SH, Wellenius GA, Wilker EH, Mostofsky E, Mittleman MA: Residential proximity to major roadways and renal function. J Epidemiol Community Health 2013;67:629-634.

10 Ali BH, Al Moundhri MS, Tag EM, Nemmar A, Tanira MO: The ameliorative effect of cysteine prodrug L-2oxothiazolidine-4-carboxylic acid on cisplatin-induced nephrotoxicity in rats. Fundam Clin Pharmacol 2007;21:547-553.

11 Nemmar A, Al Salam S, Zia S, Yasin J, Al H, I, Ali BH: Diesel exhaust particles in the lung aggravate experimental acute renal failure. Toxicol Sci 2010;113:267-277.

12 Nemmar A, Beegam S, Yuvaraju P, Yasin J, Fahim MA, Kazzam EE, Alhaddabi I, Ali BH: Potentiation of cisplatin-induced nephrotoxicity by repeated exposure to diesel exhaust particles: An experimental study in rats. Exp Biol Med (Maywood) 2014;239:1036-1044.

13 Waly MI, Ali BH, Nemmar A: Acute effects of diesel exhaust particles and cisplatin on oxidative stress in cultured human kidney (HEK 293) cells, and the influence of curcumin thereon. Toxicol In Vitro 2013;27:2299-2304.

14 Nemmar A, Al-Salam S, Beegam S, Yuvaraju P, Yasin J, Ali BH: Pancreatic effects of diesel exhaust particles in mice with type 1 diabetes mellitus. Cell Physiol Biochem 2014;33:413-422.

15 Nemmar A, Al DR, Alamiri J, Al HS, Al SH, Beegam S, Yuvaraju P, Yasin J, Ali BH: Diesel Exhaust Particles Induce Impairment of Vascular and Cardiac Homeostasis in Mice: Ameliorative Effect of Emodin. Cell Physiol Biochem 2015;36:1517-1526.

16 Nemmar A, Al Maskari S, Ali BH, Al Amri IS: Cardiovascular and lung inflammatory effects induced by systemically administered diesel exhaust particles in rats. Am J Physiol Lung Cell Mol Physiol 2007;292:L664-L670.

17 Ali BH, Al-Salam S, Al ZM, Waly MI, Ramkumar A, Beegam S, Al-Lawati I, Adham SA, Nemmar A: New model for adenine-induced chronic renal failure in mice, and the effect of gum acacia treatment thereon: comparison with rats. J Pharmacol Toxicol Methods 2013;68:384-393.

18 Nemmar A, Al HA, Al HN, Yuvaraju P, Beegam S, Yasin J, Elwasila M, Ali BH, Adeghate E: Early pulmonary events of nose-only water pipe (shisha) smoking exposure in mice. Physiol Rep 2015;3. 


\section{Cellular Physiology Cell Physiol Biochem 2016;38:1703-1713 and Biochemistry Published online: May 03, $2016 \quad \begin{aligned} & \text { DOI: 10.1159/000443109 } \\ & \begin{array}{l}\text { C } 2016 \text { The Author(s). Published by S. Karger AG, Basel } \\ \text { www.karger.com/cpb }\end{array}\end{aligned}$ \\ Nemmar et al.: Prolonged Exposure to Diesel Particles and Chronic Renal Failure}

19 Nemmar A, Yuvaraju P, Beegam S, Ali BH: Short-term nose-only water-pipe (shisha) smoking exposure accelerates coagulation and causes cardiac inflammation and oxidative stress in mice. Cell Physiol Biochem 2015;35:829-840.

20 Nemmar A, Yuvaraju P, Beegam S, Yasin J, Dhaheri RA, Fahim MA, Ali BH: In vitro platelet aggregation and oxidative stress caused by amorphous silica nanoparticles. Int J Physiol Pathophysiol Pharmacol 2015; 7:27-33.

21 Ali BH, Adham SA, Al Balushi KA, Shalaby A, Waly MI, Manoj P, Beegam S, Yuvaraju P, Nemmar A: Reproductive toxicity to male mice of nose only exposure to water- pipe smoke. Cell Physiol Biochem 2015;35:29-37.

22 Nemmar A, Beegam S, Yuvaraju P, Yasin J, Shahin A, Ali BH: Interaction of amorphous silica nanoparticles with erythrocytes in vitro: role of oxidative stress. Cell Physiol Biochem 2014;34:255-265.

23 Attoub S, Karam SM, Nemmar A, Arafat K, John A, Al-Dhaheri W, Al Sultan MA, Raza H: Short-term effects of oral administration of Pistacia lentiscus oil on tissue-specific toxicity and drug metabolizing enzymes in mice. Cell Physiol Biochem 2014;33:1400-1410.

24 Olive PL, Banath JP, Fjell CD: DNA strand breakage and DNA structure influence staining with propidium iodide using the alkaline comet assay. Cytometry 1994;16:305-312.

25 Hartmann A, Speit G: The contribution of cytotoxicity to DNA-effects in the single cell gel test (comet assay). Toxicol Lett 1997;90:183-188.

26 Gao Z, Liu G, Hu Z, Li X, Yang X, Jiang B, Li X: Grape seed proanthocyanidin extract protects from cisplatininduced nephrotoxicity by inhibiting endoplasmic reticulum stress-induced apoptosis. Mol Med Rep 2014;9:801-807.

27 Spencer-Hwang R, Knutsen SF, Soret S, Ghamsary M, Beeson WL, Oda K, Shavlik D, Jaipaul N: Ambient air pollutants and risk of fatal coronary heart disease among kidney transplant recipients. Am J Kidney Dis 2011;58:608-616.

28 Ali BH, Al Salam S, Al Husseni I, Kayed RR, Al Masroori N, Al Harthi T, Al Zaabi M, Nemmar A: Effects of Gum Arabic in rats with adenine-induced chronic renal failure. Exp Biol Med 2010;235:373-382.

29 Ali BH, Al-Husseni I, Beegam S, Al-Shukaili A, Nemmar A, Schierling S, Queisser N, Schupp N: Effect of gum arabic on oxidative stress and inflammation in adenine-induced chronic renal failure in rats. PLoS One 2013;8:e55242.

30 Ali BH, Inuwa I, Al ZM, Al BS, Al IH, Ramkumar A, Madanagopal T, Nemmar A, Malheiros DM, Zatz R: Renal and myocardial histopathology and morphometry in rats with adenine - induced chronic renal failure: influence of gum acacia. Cell Physiol Biochem 2014;34:818-828.

31 Ali BH, Al ZM, Adham SA, Yasin J, Nemmar A, Schupp N: Therapeutic Effect of Chrysin on Adenine-Induced Chronic Kidney Disease in Rats. Cell Physiol Biochem 2016;38:248-257.

32 Mutlu GM, Green D, Bellmeyer A, Baker CM, Burgess Z, Rajamannan N, Christman JW, Foiles N, Kamp DW, Ghio AJ, Chandel NS, Dean DA, Sznajder JI, Budinger GR: Ambient particulate matter accelerates coagulation via an IL-6-dependent pathway. J Clin Invest 2007;117:2952-2961.

33 Nemmar A, Subramaniyan D, Ali BH: Protective effect of curcumin on pulmonary and cardiovascular effects induced by repeated exposure to diesel exhaust particles in mice. PLoS One 2012;7:e39554.

34 Driscoll KE, Costa DL, Hatch G, Henderson R, Oberdorster G, Salem H, Schlesinger RB: Intratracheal instillation as an exposure technique for the evaluation of respiratory tract toxicity: uses and limitations. Toxicol Sci 2000;55:24-35.

35 Cachofeiro V, Goicochea M, de Vinuesa SG, Oubina P, Lahera V, Luno J: Oxidative stress and inflammation, a link between chronic kidney disease and cardiovascular disease. Kidney Int Suppl 2008;S4-S9.

36 Ali BH, Al ZM, Shalaby A, Manoj P, Waly MI, Yasin J, Fahim M, Nemmar A: The effect of thymoquinone treatment on the combined renal and pulmonary toxicity of cisplatin and diesel exhaust particles. Exp Biol Med (Maywood) 2015;240:1698-1707.

37 Diwan V, Mistry A, Gobe G, Brown L: Adenine-induced chronic kidney and cardiovascular damage in rats. J Pharmacol Toxicol Methods 2013;68:197-207.

38 Schupp N, Kolkhof P, Queisser N, Gartner S, Schmid U, Kretschmer A, Hartmann E, Oli RG, Schafer S, Stopper $\mathrm{H}$ : Mineralocorticoid receptor-mediated DNA damage in kidneys of DOCA-salt hypertensive rats. FASEB J 2011;25:968-978.

39 Ali BH, Al BK, Al-Husseini I, Mandel P, Nemmar A, Schupp N, Ribeiro DA: Gum acacia mitigates genetic damage in adenine-induced chronic renal failure in rats. Eur J Clin Invest 2015;45:1221-1227.

40 Cao Q, Harris DC, Wang Y: Macrophages in kidney injury, inflammation, and fibrosis. Physiology (Bethesda) 2015;30:183-194.

41 Oparil S, Zaman MA, Calhoun DA: Pathogenesis of hypertension. Ann Intern Med 2003;139:761-776. 